\title{
MEASURING LEGISLATIVE EFFECTIVENESS IN THE MISSOURI \\ GENERAL ASSEMBLY: A LONGITUDINAL STUDY
}

\author{
Mark C. Ellickson \\ (Southwest Missouri State University) \\ Donald E. Whistler \\ (University of Central Arkansas)
}

\section{Introduction}

The responsibilities and duties of a state legislator are numerous. In addition to their policymaking efforts,legislators are expected to provide constituent service, preside over the bureaucracy, resolve conflict, educate the public, promote good government, and campaign for re-election to name a few (Rosenthal, 1974: 11-12; Jewell and Patterson, 1986: 9-13). However, if there is one activity that dominates a legislator's time and energy when they are in session, it is the sponsoring of legislation and promoting its enactment into law (Rosenthal, 1981: 255-256; Patterson, 1983: 165).

Recognizing that some representatives are more successful than others at navigating their bills through the legislative labyrinth, one would expect legislative output to reflect the policy prejudices and predilections of this successful elite. Consequently, identifying the determinants of legislative effectiveness ${ }^{1}$ is an important antecedent to understanding and predicting state legislative output. ${ }^{2}$

In this paper we will assess the impact of a series of legislative, personal, district-related, and reputational characteristics on legislators' performance in the Missouri House over a period of twelve years spanning four decades. ${ }^{3}$ The longitudinal format of this study is designed to avoid some of the pitfalls associated with cross-sectional designs which currently dominate this area of inquiry.

This paper will also examine the question of legislative effectiveness from a majority-minority party perspective. Few legislative power studies have addressed the interactive effects of majority-minority party status on other variables despite warnings to the contrary (Meyer, 1980: 581). 
Finally, we will present a new method for directly measuring effectiveness within a state legislature. We believe this measure to be an important addition to previous efforts in this area of research.

\section{Literature Review and Model Development}

As legislators compete to successfully maneuver their bills through the legislative arena some are presumably advantaged by virtue of possessing certain attributes. For example, formal office (usually defined in terms of one's party position and/or committee position) is frequently cited as an important prerequisite of legislative influence (Best, 1971; Meyer, 1980; Hamm et al, 1983; Whistler and Ellickson, 1988). Formal position is believed to confer strategic access and control over important organizational resources which in turn are parlayed into legislative influence. Frantzich (1979: 417, 421), for instance, has noted that Congressional House leaders tend to introduce more bills and are more likely to see those bills passed than non-leaders.

Seniority is another characteristic often associated with legislative power. Long tenure is equated with extensive knowledge of the complex rules of the legislative process, with a "feel" for what will pass and what will fail, with deference from junior colleagues, and positions of leadership (Francis, 1962; Frantzich, 1979; Meyer, 1980; Squire, 1988).

Majority party status has also been linked to legislative effectiveness. Citing a greater responsibility for policy development and the inherent political advantages that accrue to the majority party under these conditions, several scholars have addressed the importance of this variable (Frantzich, 1979; Meyer, 1980; Hamm et al, 1983).

Some students of legislatures have concentrated on personal factors such as age (Jewell, 1969: 32), gender (Rosenthal, 1981: 30-31), race (Rosenthal, 1981: 30-31; Hamm et al, 1983), education and occupation (Meyer, 1980; Rosenthal, 1989: 75-76). In short, state legislators are typically educated middle-aged white males from prominent economic activities in a state and/or from law firms (Keefe and Ogul, 1985: 111115).

Other legislative pundits have concerned themselves with the impact of district-related factors on legislative performance. Jewell and Patterson's (1966) study of state legislatures uncovered that influential legislators hailed from safe districts. At the federal level, Matthews (1960), Clapp (1963), and Fenno $(1966,1973)$ concluded that legislators from unsafe districts (i.e., highly competitive) were seldom considered influen- 
tial and rarely achieved important committee positions or assignments.

A second factor, urban-rural district representation, has historically been a major source of legislative conflict (Francis, 1967). Until one man, one vote became a reality in the 1960 's, most state legislatures were severely malapportioned permitting rural representatives to wield excessive power at the expense of their urban counterparts. ${ }^{4}$ Rural power, however, has been slow to dissipate. Tickameyer (1983), for example, reported in her study of the 1977 North Carolina General Assembly that rural district legislators continued to exercise significantly greater influence than urban district representatives. Moreover, some southern states have sought to perpetuate rural control by placing rural conservative Democrats in key leadership roles (Saffell, 1987: 122).

The preceding list of variables by no means depletes the inventory of attributes associated with legislative effectiveness. They are, however, quite representative of the types of variables one finds in this genre of literature (Meyer, 1980). It is the conceptualization and operationalization of the dependent variable, legislative effectiveness, that is more problematic (Janda, 1972: 57; Burns, 1978: 18-19; Bass, 1981: 10, 169). A number of scholars have elected to use "perceived influence" (i.e., reputation) rather than "actual influence" as their measure of legislative effectiveness (Francis, 1962; Best, 1971; Meyer, 1980). Unfortunately, the "reputation for influence" approach contains the well-known flaw that potential for influence does not necessarily result in actual influence (Dahl, 1976: 28-30).

In this paper we will define legislative effectiveness as the ability to successfully maneuver one's legislation through the legislative process. This approach reflects Dahl's (1957) view of political influence as a relationship between political actors, i.e., "A has power over B to the extent that he can get something that B would not otherwise do" (p. 203). Clearly the process of enacting legislation forces members of a legislature to make hard decisions concerning which pieces of legislation to accept and which to reject.

Employment of legislators' bill-passage success rates as a measure of legislative effectiveness is not without risk. The use of amendments to alter a bill's content can result in legislation antagonistic to the author's original intent. Secondly, some legislators make a career out of blocking legislation rather than facilitating it. Hence, they are powerful not for what they produce, but for what they destroy. Despite these limitations, it is fair to argue that state legislatures have a primary policy-making role and the passage of one's legislation is an important manifestation of one's power 
and influence in this particular body (Rosenthal, 1981: 255-256).

Finally, we have elected to incorporate "reputation for influence" as an intervening variable in our model of legislative effectiveness. As shown in Figure 1 below, legislative status, personal attributes, districtrelated factors, and reputation for influence are all treated as determinants of legislative effectiveness. Reputation for influence, as an intervening variable, is projected to have direct consequences for success in a legislative body as a result of one's legislative, personal, and district-related characteristics.

\section{Research Design: Setting and Measurements}

The data for this study were drawn from six regular sessions of the lower house of the Missouri General Assembly spanning four decades. ${ }^{5}$ The 70th (1959-60) and 71st (1961-62) sessions reflected a relatively quiet era dominated by rural interests and as yet undisturbed by the civil rights and reapportionment decisions of the mid-1960's. On the other hand, the 74th (1967-68) and 78th (1975-76) assemblies represented time periods marked by intense social, economic, and political unrest. The final two sessions examined, the 83rd (1985-86) and 84th (1987-88), symbolized an era of growing professionalism and competency within the Assembly characteristic of many state legislatures of the 1980's (Rosenthal, 1989: 70-71).

In every session the Democrats are the majority party in the House (and Senate), however, in the 78th, 83rd, and 84th sessions, the governorship is controlled by the Republicans. The diversity of these legislative sessions allows us to test our hypotheses under a variety of social, economic, and political conditions. It is this aspect that makes longitudinal studies so advantageous.

In Figure 1, the three boxes on the far left represent the various categories of exogenous variables associated with legislative effectiveness. The specific measures of the legislative, personal, and districtrelated attributes are described in Appendix A. Our single endogenous variable, reputation for influence, was obtained by way of a mailed questionnaire. ${ }^{6}$ The questionnaire, completed by 89 out of 163 House members $(54.6 \%)$ contained the following two questions:

Question 1: "If you were to name four or five legislators who are most effective at getting bills passed, whom would you name?" 
Figure 1

Model of Legislative Effectiveness

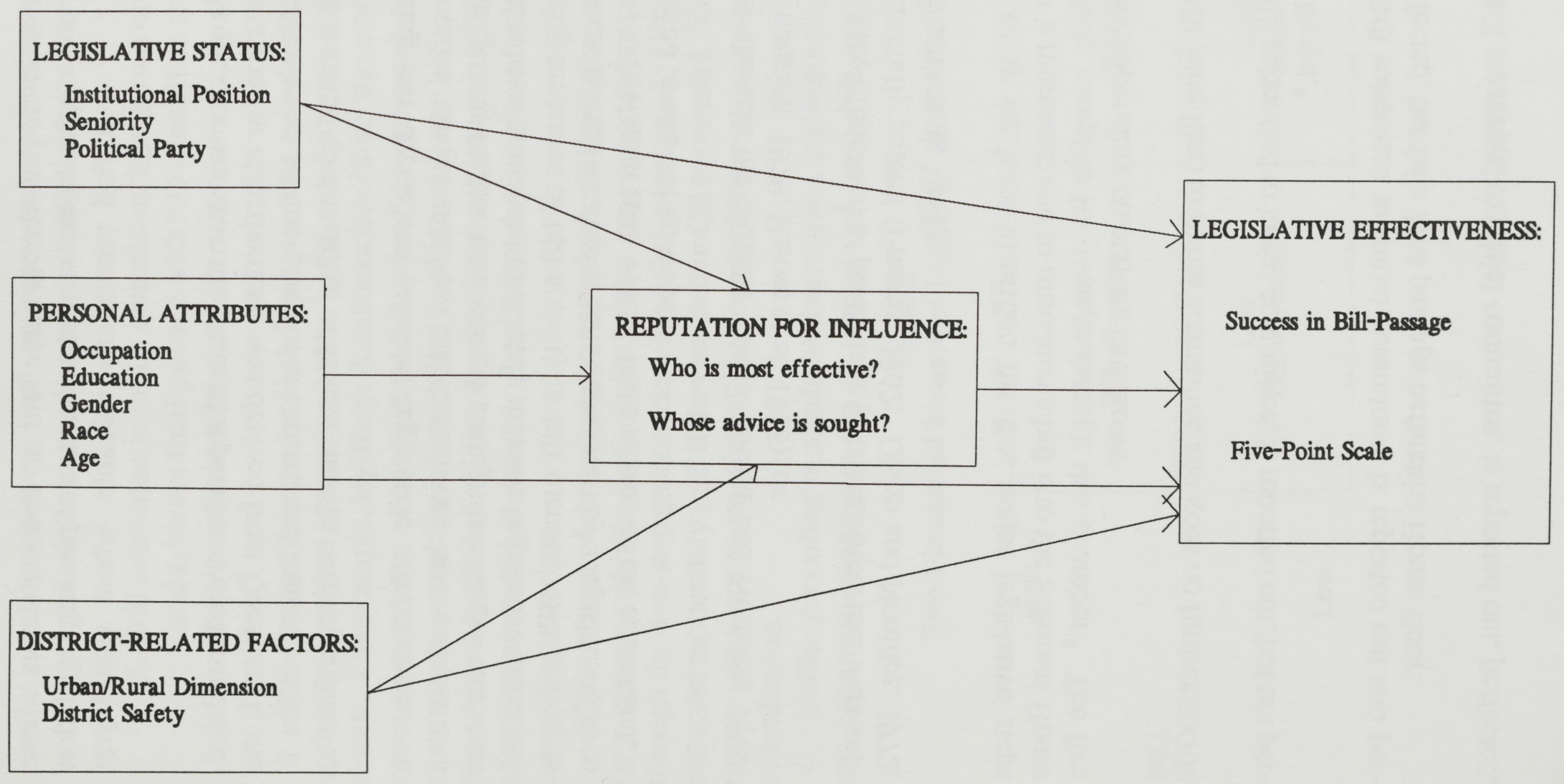


and achieves final passage, but encounters committee amendment(s) and/or substitute(s) along the way.

5. Bill submitted to initial committee, is reported out, perfected, and achieves final passage with NO committee amendment(s) and/or substitute(s) along the way.

Bill-passage success for each legislator was calculated by "scoring" each bill submitted (according to the index noted above) and totaling the results. For example, legislator A submits five bills: three of the bills are never reported out of committee or receive "do not pass" recommendations which essentially kill the bills (1 point each), one bill is reported out, is perfected, but fails final House vote ( 3 points), and one bill becomes law after it is amended (4 points). Legislator $A$ then, is accorded 10 points using this procedure.

This sysiem of measurement rewards those legislators who submit a large quantity of bills (active) AND who are successful at pushing them through the five-step process described above (success). Other legislators can score moderately well if they are active OR successful. Those who are neither active nor successful will be accorded low scores under this system of evaluation.

Unlike prevailing methods of determining legislative effectiveness, this approach emphasizes the importance of both bill activity and bill

Figure 2

Two-Dimensional Measure of Legislative Effectiveness

BILL SUCCESS

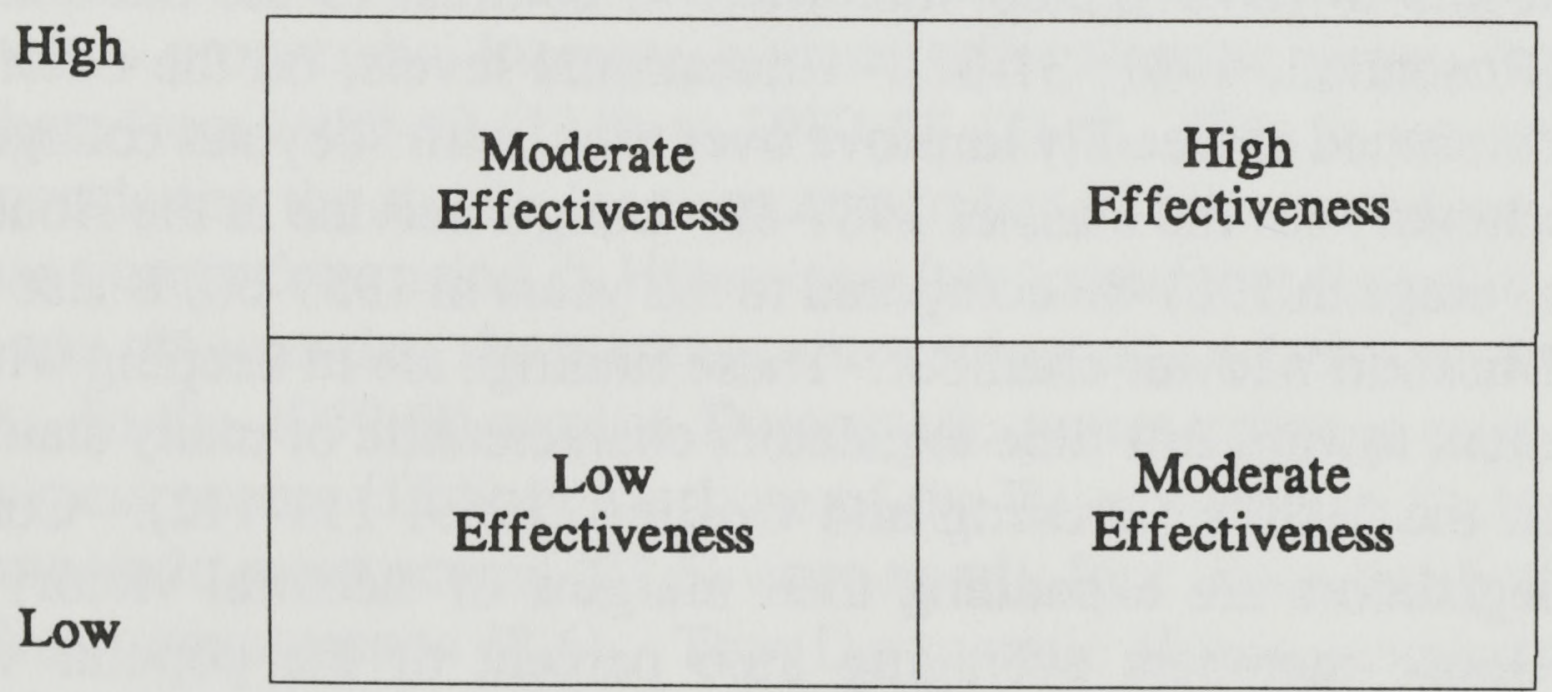


success in a single measure. Moreover, bill success is conceptualized as a process consisting of five distinct steps, not just one. We believe this twodimensional approach to be an improvement over current one-dimensional schemes.

\section{Description of Missouri House on Independent and Dependent Variables}

The personal, legislative, and district-related characteristics of Missouri House members (both aggregate and by political party) are displayed in Table 1 (see tables at end of article).

Beginning with the aggregate totals and viewing our results longitudinally, we note that male domination of the Missouri House has slowly eroded over thirty years. Whereas males had once accounted for over 99 percent of the House membership, by 1987 their numbers had declined to approximately 80 percent of the membership. These percentage changes over time are quite comparable to those reported in other states (Rosenthal, 1981: 30; Nechemias, 1987: 125; Dresang and Gosling, 1989: 111). Black representation increased from 2.6 percent (1959-60) to 6.3 percent (198788) reaching a peak of 7.5 percent during the $1975-76$ session. These figures compare favorably with the 5.4 percent black state legislator average (1980) across the nation (Rosenthal, 1981: 30; Dresang and Gosling, 1989: 111).

Age-wise House members are typically in their mid-forties to earlyfifties (median values). A trend toward younger legislators, however, seems to have abated somewhat in contrast to the national movement (Rosenthal, 1981: 31-32). Educational levels, on the other hand, have continued to steadily improve over time, with "beyond college" the modal category for the class of 1987-88. Longer service in the House (8.9 years average in 1987-88 compared to 5.2 years in 1959-60) is also reflective of Missouri's lower chamber. These findings are in keeping with the movement toward full-time legislators characteristic of many state legislatures in the 1980's (Dresang and Gosling, 1989: 111-112). Concomitantly, legislators are expanding their margins of electoral victory with recent House members averaging 86.6 percent of the popular vote in their districts compared to 69.9 percent in the early 1960 's.

Finally, we note the impact of Reynolds v. Sims (1964) on urban representation in the Missouri House. The number of urban representatives more than doubled from 1959-62 to 1967-68, while rural representa- 
tion dropped dramatically from 70 percent to 30 percent. Today urban representatives continue to enjoy a 2 to 1 margin in membership over their rural colleagues in the House.

Examination of Democratic and Republican representatives on these various attributes indicated that legislators of both parties had some similarities as well as differences. Republicans held slightly more prestigious occupations than Democrats; they tended to be better educated and older, and they faced stronger competition in the general election campaigns. Democrats, in contrast, were more likely to have longer tenure in the legislature; to be female or black (there were no black Republican legislators in the six sessions examined); and to represent urban interests.

Turning to the dependent variable, our hypotheses concerning the attributes affecting legislative effectiveness assume that there are significant variations, subject to explanation, among members of the Missouri House. The data in Table 2 indicate that there are indeed substantial variations within and across each of the six sessions. For example, in the 70th, 71st, and 74th General Assemblies, it was not unusual for 40 to 50 percent of House bills introduced to achieve final passage (within the House) and for 25 to 30 percent of those bills to do so without amendments and/or committee substitutes. During the 78th, 83rd, and 84th session only 25 percent or so of the House bills passed successfully through that chamber and only 10 percent did so without amendments/substitutes. This reduction in bill passage has been offset by the increasing number of bills being disposed of very early in the legislative process.

In Table 3 we have displayed the means, ranges, and standard deviations of individual legislator sponsored bills as measured on the Five-Point Legislative Effectiveness Scale. Viewing the House as a whole, we note a progressive increase in mean effectiveness scores for House members from 1959-60 (13.7) to 1987-88 (25.4). This is not too surprising considering the steady increase in number of bills introduced into the House during this period. ${ }^{10}$ However, after controlling for political party, it was obvious that the increase was exclusively a Democratic phenomenon. In the 1959-60 session Democratic representatives averaged effectiveness scores (15.6) twice those of the Republicans (8.8), by 1987-88 Democratic mean scores (33.5) were nearly four times those of their Republican counterparts (8.6). That Democratic House members have seen their mean effectiveness scores more than double in thirty years, while Republican scores have remained virtually unchanged is in large part due to their majority party status enjoyed since $1952 .{ }^{11}$ 


\section{Expectations and Findings}

In this section we assess the impact of four categories of explanatory variables on legislative effectiveness in the Missouri House. We also examine the impact of legislative, personal, and district-related factors on our two measures of reputation for influence. The analysis incorporates both longitudinal and majority-minority party comparisons.

Figure 1 predicts that certain legislative, personal, and districtrelated characteristics will enhance a legislator's prospect of successfully steering his/her bills through the House. Specifically, we expect legislative effectiveness to be associated with middle-aged, better educated white male legislators with prestigious occupations; with legislators who hold positions of party leadership and seniority, as well as, "reputations" for effectiveness and influence in the legislature; with representatives who hail from electorally safe districts; and with Democrats.

Moreover, rural legislators are projected to be more effective than urban legislators in the first three sessions (70th, 71st, and 74th), while the reverse is anticipated for the latter three sessions (78th, 83rd and 84th).

Examination of Table 4 (aggregate only) indicates strong support for our hy potheses when using legislative status variables (institutional position, seniority, and political party) and the two measures of "reputation;" moderate support when testing for educational level, age, and occupational prestige; and limited support when examining district-related factors (urban/rural districts, district safety) and gender/race differences.

In general then, our aggregate findings suggest the profile of a successful and effective legislator (Missouri House) to be that of a relatively young, well-educated and respected senior Democrat with a leadership position and prestigious occupation outside the legislature (most notably, the practice of law). Because institutional position and seniority are significantly related in four of the six sessions analyzed, it is possible that our findings with respect to seniority are spurious, i.e., a tendency for seniors to also be leaders. ${ }^{12}$ However, after controlling for leadership, the more senior non-leaders were still significantly more effective than junior non-leaders. ${ }^{13}$

To a lesser degree, the results implied that an effective legislator is also one who is white, male, and a representative from a safe urban district.

Curiously, our results indicated that younger representatives were consistently more effective, regardless of party, than older members. Apparently, in the Missouri House you must make a name for yourself early in your career, otherwise the window of opportunity is substantially 
narrowed. Although this finding contradicts conventional wisdom, it is in keeping with the rise of professional, competitive state legislatures discussed earlier.

While the above profile tends to hold true for Democratic members longitudinally, Republican avenues to legislative effectiveness are considerably more limited and inconsistent over time (see Table 4). For example, in the 1959-60, 1967-68, 1985-86, and 1987-88 sessions, there were virtually no statistically significant relationships between any of the explanatory variables and Republican legislative effectiveness. With regard to the remaining two sessions (1961-62 and 1975-76), only age (young), education (high), and urbanism (urban) were consistently identified as meaningful paths to influence. Interestingly, not even institutional position could guarantee legislative influence for Republican members.

For both parties, urban legislators and those from safe districts were apt to be slightly more successful at getting their legislation passed than rural representations and those from unsafe districts. Longitudinally, the findings were inconsistent and the eta coefficients generally quite weak. Gender and sex also exhibited weak explanatory powers for both parties.

Finally, Democratic members with "reputations" for effectiveness and advice enjoyed a significantly higher level of success than Democratic members lacking these traits. Neither measure was related to Republican success in the Missouri House.

Figure 1 also anticipates that the legislative, personal, and districtrelated attributes will affect a legislator's reputation for influence in a manner similar to that for legislative effectiveness. ${ }^{14}$ The aggregate results in Table 5 indicated that reputations for effectiveness and advice-giving were primarily attributed to Democratic leaders. Few Republicans were identified as effective in passing legislation and as advice-givers. Those that were tended to be well-educated, young representatives from safe urban districts with prestigious outside occupations. For Democrats, measures of reputation were essentially a function of leadership position.

\section{Conclusion}

Be the matters small or great, frivolous or grave, which busy it, its aim is to have laws always a-making (Wilson, 1956: 193).

Woodrow Wilson was one of the first political scientists to recognize the policy-making appeal inherent within legislatures. The lure of passing 
legislation has not abated since Wilson's century-old observation and, if anything, has burgeoned. Since the legislative process rewards those who are successful, i.e., policy outputs, it is important to identify the attributes associated with this effective subgroup.

In this paper we have attempted to identify important determinants of legislative effectiveness. Employing a unique two-dimensional approach to measure legislative effectiveness, our longitudinal results indicated that legislative status variables and "reputations" for influence best predicted levels of effectiveness (see Figure 1). Institutional position, in particular, was consistently associated with high levels of success.

Personal factors, such as age, educational level, and occupational prestige were also singled out as useful explanatory variables. There was some evidence suggesting the importance of district-related characteristics on legislative effectiveness, but the findings were scattered and inconsistent over time. Expectations with regard to race and gender, however, were not borne out in the analysis. Blacks and females in the Missouri House generally fared no worse (or better) than whites and males in the legislative arena.

Undoubtedly the most important finding was that separate analyses of Democratic (majority party) and Republican (minority party) representatives yielded substantially different models of legislative effectiveness. Whereas Democratic members could count on institutional position, seniority, educational level, occupational prestige, age, and reputation as proven guides to legislative success, Republicans had no clear paths to follow. Moreover, the longitudinally results suggested that the few avenues once opened to Republicans (i.e., young, well-educated urban Republican leaders) are now closed.

The years of Democratic dominance (a 2 to 1 margin since 1952) in the House have clearly taken their toll on Republican efforts to establish indeperident power bases. Today, Republicans who wish to wield power in the Missouri House must first seek out Democratic allies and those relationships are unstable at best. In short, those who are legislatively effective in the Missouri House represent a non-random subgroup of legislators.

\section{Notes}

${ }^{1}$ The terms legislative effectiveness, legislative influence, and legislative power are used interchangeably throughout the study.

${ }^{2}$ For an interesting analysis of the distribution of power in the U.S. House of Representatives, see Frantzich (1979). 
${ }^{3} 1959-1960 ; 1961-1962 ; 1967-1968 ; 1975-1976 ; 1985-1986$; and 1987-1988.

${ }^{4}$ Leuthold and Carter (1981) note that in 1960 "the Missouri House of Representatives was one of the five least equitably apportioned lower chambers in the nation..." (181).

${ }^{5}$ The speaker and those legislators serving less than 100 percent of their terms were excluded from analysis in each of the six sessions examined.

${ }^{6}$ The questionnaire was completed for the 84th session (1987-88) only.

${ }^{7}$ See also, Whistler and Dunn, 1983; Whistler and Ellickson, 1988, for use of this questionnaire in the Arkansas General Assembly.

${ }^{8}$ In measuring legislative effectiveness it was felt that a legislator's "sphere of influence" was limited primarily to the chamber he/she resided in. Consequently, in this study "bill passage" refers to a bill clearing the house chamber and not necessarily to one passed into law.

${ }^{9}$ If a bill is reported favorably out of committee or a substitute is recommended, it is placed on the "perfection calendar" and when its turn comes up for consideration it is debated on the floor of the orginating house. If a substitute is recommended by the committee or if committee amendments are attached to the bill, they are first presented, debated and voted upon. Further amendments can then be proposed by other members with their changes designated as House or Senate amendments to differentiate from the committee amendments. When all amendments have been considered, a motion is made to declare the bill perfected. Perfection is usually voted on a voice vote but on the request of five members, a roll call shall be taken. If a majority of members vote to perfect, the bill is reprinted in its original or amended form.

${ }^{10}$ In 1970 the voters of Missouri adopted a constitutional amendment establishing annual sessions of the legislature. Prior to this the Missouri legislature met once every two years.

${ }^{11}$ The speaker appoints all members, including Republicans, to committees. Thus, he can minimize Republican influence and effectiveness by assigning the most capable Republicans to the least significant committees.

${ }^{12}$ The $\mathrm{r}$ values between the dichotomous seniority and institutional position variables for the 1967-68, 1975-76, 1985-86, and 1987-88 sessions were: $.26, .35, .28$, and .27 , respectively, all significant at the .001 level.

${ }^{13}$ The eta values for the $1967-68,1975-76,1985-86$, and 1987-88 sessions examining legislative effectiveness and seniority while controlling for institutional position were: $.29, .21, .30$, and .28 , respectively, all significant at the .001 level except for 1975 76 (.05 level).

${ }^{14} \mathrm{We}$ expected both measures of reputation to be related. The $\mathrm{r}$ value between these two measures was .54 , significant at the .001 level.

Authors' Note: Our appreciation is extended to Pamela McWherter and Joan Twiton of Southwest Missouri State University for research assistance on this project. 
Mark C. Ellickson and Donald E. Whistler

\section{Table 1}

Personal, Legislative, and District-Related Attributes of Missouri House Members

$$
\frac{1959-1960}{\text { Aggregate Demo Rep }}
$$

\section{House}

Membership

(\%)

$154 \quad \begin{array}{rr}109 & 45 \\ (70.8) & (29.2)\end{array}$

155

1961-1962

Aggregate Demo Rep

Gender

Male
$\%$

Female

$\%$

Race
White
$\%$
Black
$\%$

Age (median)

Education

(modal

category)

Occupational

Prestige

(mean scores)

Seniority

(mean years)

District

Rural (\%)

$(70.1) \quad(64.2) \quad(84.4)$

(29.9) (35.8) (15.6)

45

(97.4) (96.3)

44

(2.6) (3.7)

45

(96.8) (95.4)

(3.2) (4.6)

0

$\begin{array}{lll}51.0 & 50.5 & 53.5\end{array}$

High High High

School School School

$\begin{array}{lll}75.3 & 74.9 & 76.2\end{array}$

$5.2 \quad 5.1$

5.4

Urban (\%)

Percentage of

District Vote

by Winning

House Member

(mean \%)
$(76.1) \quad(76.6) \quad(75.0) \quad(69.9) \quad(72.2) \quad(65.8)$

$\begin{array}{rrr}154 & 97 & 57 \\ (99.4) & (99.0) & \\ 1 & 1 & 0 \\ (.6) & (1.0) & \end{array}$

$\begin{array}{rrr}151 & 94 & 57 \\ (97.4) & (95.9) & \\ 4 & 4 & 0 \\ (2.6) & (4.1) & \end{array}$

$51.0 \quad 48.5 \quad 55.0$

High High High School School School

$\begin{array}{lll}75.5 & 75.4 & 75.9\end{array}$

$5.4 \quad 5.5 \quad 5.4$

(69.0) (60.2) (84.2)

(31.0) (39.8) (15.8) 
Measuring Legislative Effectiveness in the Missouri General Assembly

Table 1

Personal, Legislative, and District-Related Attributes
of Missouri House Members

House

Membership

(\%)

Gender

Male

$\%$

Female

$\%$

Race

White

$\%$

Black

$\%$

Age (median)

Education

(modal

category)

Occupational

Prestige

(mean scores)

Seniority

(mean years)

District

Rural (\%)

$(30.9) \quad(24.8) \quad(42.1)$

(69.1) (75.2) (57.9)

$\begin{array}{rrr}155 & 100 & 55 \\ (95.7) & (95.2) & (96.5)\end{array}$

$7 \quad 5$

(4.3) (4.8)

(3.5)

150

93

(92.6) (88.6)

12

12

(7.4) (11.4)

$46.0 \quad 44.0$

49.0

High High Beyond

School School College

$\begin{array}{lll}76.1 & 75.5 & 77.4\end{array}$

$\begin{array}{lll}4.5 & 5.0 & 3.4\end{array}$

6.6

6.7

6.6

$(93.2) \quad(92.9) \quad(93.8)$

$\begin{array}{lll}11 & 8 & 3\end{array}$

(6.8) (7.1)

161

(70.2) (29.8)

Urban (\%)

$\frac{1975-1976}{\text { Aggregate Demo }}$

Percentage of

District Vote

by Winning

House Member

(mean \%)

(70.9) (73.4) (66.2)

(77.1) (79.6)

(71.3) 
Mark C. Ellickson and Donald E. Whistler

Table 1

Personal, Legislative, and District-Related Attributes of Missouri House Members

$\frac{1985-1986}{\text { Aggregate Demo Rep }}$

House

Membership

(\%)

Gender

Male

$\%$

Female

$\%$

161

$105 \quad 56$

(65.2) (34.8)

$\begin{array}{lll}136 & 88 & 48\end{array}$

$\begin{array}{lll}(84.5) \quad(83.8) \quad(85.7) & \end{array}$

25

$17 \quad 8$

(15.5) (16.2) (14.3)

Race

White

$\%$

Black

$\%$

Age (median)

48.5

151

95
$(90.5)$
10
$(9.5)$

56

(93.8) (90.5)

10

(6.2)

9.5)

0

$47.0 \quad 52.0$

Education

(modal category)
Beyond

College College College

$\frac{1987-1988}{\text { Aggregate Demo Rep }}$

160

108

52

(67.5) (32.5)

$\begin{array}{rrr}131 & 86 & 45 \\ (81.9) & (79.6) & (86.5) \\ 29 & 22 & 7 \\ (18.1) & (20.4) & (13.5)\end{array}$

$\begin{array}{rrr}150 & 98 & 52 \\ (93.8) & (90.7) & \\ 10 & 10 & 0 \\ (6.3) & (9.3) & \end{array}$

$49.0 \quad 47.0$

54.0

Occupational

Prestige

(mean scores)

$\begin{array}{lll}51.1 & 50.0 \quad 53.0\end{array}$

$\begin{array}{lll}51.5 & 50.1 \quad 54.0\end{array}$

Seniority

8.3

8.9

7.1

8.9

9.4

7.9

(mean years)

District

Rural (\%)

(36.0) (35.2) (37.5)

(35.0) (36.1)

Urban (\%)

$(64.0) \quad(64.8) \quad(62.5)$

(65.0) (63.9)

(67.3)

Percentage of

District Vote

by Winning

House Member (86.6) (89.1) (81.9)

(81.8) (83.5)

(78.3)

(mean \%) 
Table 2

DISTRIBUTION OF BILLS ${ }^{\text {a }}$ ON FIVE-POINT SCALE IN THE MISSOURI HOUSE

\begin{tabular}{|c|c|c|c|c|c|c|}
\hline FIVE POINT & \multicolumn{2}{|c|}{$\begin{array}{c}\text { 70th G.A. } \\
1959-1960 \\
\end{array}$} & \multicolumn{2}{|c|}{$\begin{array}{c}\text { 71st G.A. } \\
1961 \text { - } 1962 \\
\end{array}$} & \multicolumn{2}{|c|}{$\begin{array}{c}\text { 74th G.A. } \\
1967-1968\end{array}$} \\
\hline SCALE & $\underline{\%}$ & & $\underline{\%}$ & & $\underline{\%}$ & \\
\hline 1 & 37 & $(215)$ & 42 & (317) & 40 & (354) \\
\hline 2 & 7 & (38) & 7 & (54) & 18 & (154) \\
\hline 3 & 5 & (30) & 5 & (38) & 2 & (14) \\
\hline 4 & 16 & (90) & 15 & (112) & 18 & (156) \\
\hline 5 & 35 & $(203)$ & 31 & (237) & 23 & (199) \\
\hline & $0 \%$ & $\mathrm{~N}=576$ & $100 \%$ & $N=758$ & $101 \%$ & $\mathrm{~N}=877$ \\
\hline
\end{tabular}


Table 2 (cont.)

\begin{tabular}{|c|c|c|c|c|c|c|}
\hline \multirow{2}{*}{$\begin{array}{l}\text { FIVE POINT } \\
\text { SCALE }\end{array}$} & \multicolumn{2}{|c|}{$\begin{array}{l}\text { 70th G.A. } \\
1975-1976 \\
\end{array}$} & \multicolumn{2}{|c|}{$\begin{array}{l}\text { 83rd G.A. } \\
1985-1986 \\
\end{array}$} & \multicolumn{2}{|c|}{$\begin{array}{l}\text { 84th G.A. } \\
1987-1988 \\
\end{array}$} \\
\hline & $\%$ & & $\underline{\%}$ & & $\underline{\%}$ & \\
\hline 1 & 61 & (1116) & 54 & (903) & 56 & (1034) \\
\hline 2 & 19 & (339) & 15 & (244) & 13 & (231) \\
\hline 3 & 2 & (28) & 4 & (70) & 3 & (58) \\
\hline 4 & 9 & (155) & 14 & (238) & 16 & (303) \\
\hline \multirow[t]{2}{*}{5} & 10 & (186) & 13 & (224) & 12 & $\underline{(216)}$ \\
\hline & $101 \%$ & $\mathrm{~N}=1824$ & $100 \%$ & $\mathrm{~N}=1679$ & $101 \%$ & $\mathrm{~N}=1842$ \\
\hline
\end{tabular}

${ }^{2}$ Iricludes single-author, coauthored, and first-authored (where three or more authors) bills only. 
Measuring Legislative Effectiveness in the Missouri General Assembly

\section{Table 3}

Mean Values, Ranges, and Standard Deviations of Individual Legislator Sponsored Bills on Five-Point Scale in the Missouri House

$\frac{1959-1960}{\text { Aggregate Demo Rep }} \quad \frac{1961-1962}{\text { Aggregate Demo Rep }}$

\begin{tabular}{|c|c|c|c|c|c|c|}
\hline Mean & 13.7 & 15.6 & 8.8 & 15.9 & 20.7 & 7.6 \\
\hline Range & & $0-182$ & $0-136$ & & $0-112$ & $0-47$ \\
\hline \multirow[t]{3}{*}{ SD } & 26.7 & 28.5 & 21.2 & 20.0 & 22.8 & 9.3 \\
\hline & \multicolumn{3}{|c|}{$\begin{array}{r}1967-1968 \\
\end{array}$} & \multicolumn{3}{|c|}{$1975-1976$} \\
\hline & Aggregate & Demo & Rep & $\overline{\text { Aggregate }}$ & Demo & Rep \\
\hline Mean & 15.5 & 19.8 & 7.5 & 20.8 & 25.2 & 10.5 \\
\hline Range & & $0-98$ & $0-35$ & & $0-144$ & $0-58$ \\
\hline SD & 17.1 & 19.3 & 7.2 & 23.9 & 26.6 & 10.5 \\
\hline
\end{tabular}

$\frac{1985-1986}{\text { Aggregate Demo Rep }} \quad \frac{1987-1988}{\text { Aggregate Demo Rep }}$

$\begin{array}{lcccccc}\text { Mean } & 24.2 & 32.0 & 9.6 & 25.4 & 33.5 & 8.6 \\ \text { Range } & & 0-271 & 0-72 & & 0-296 & 0-67 \\ \text { SD } & 28.8 & 32.3 & 10.5 & 31.1 & 34.2 & 11.3\end{array}$


Mark C. Ellickson and Donald E. Whistler

\section{Table 4}

The Influence of Legislative, Personal, District-Related and Reputational Attributes on Legislative Effectiveness in the Missouri House ${ }^{a, b}$

\section{9-1960 Aggregate Demo Rep Aggregate Demo Rep}

Institutional

Position

$$
.47 * * \quad .57 * * \quad .03
$$

$.43 * * .42 * * .47 *$

Seniority

$.11 \quad .16 \quad .06$

.15

$.17 \quad .19$

Political

Party

Race

Gender

Educational

Level

$.30 * * \quad .40 * * \quad .01$

$.31 * * \quad .31 * \quad .26 *$

Age

$.26 *$

$.32 * \quad .16$

$.52 * * \quad .51 * * \quad .43 *$

Occupational

Prestige

$\begin{array}{lll}.23 * & .28 * \quad .09\end{array}$

$\begin{array}{lll}.32 * * & .31 * * & .28\end{array}$

Urban/Rural .01

$.02 \quad .05$

$.29 * *$

.19

$.47^{* *}$

District

Safety

.07

$.18 \quad .26$

.09

.10

.05 
Measuring Legislative Effectiveness in the Missouri General Assembly

\section{Table 4 (continued)}

\section{7-1968 \\ Aggregate Demo Rep Aggregate Demo Rep}

Institutional

Position

$.31 * * \quad .31 * * \quad .30 *$

$.46 * * \quad .51 * * \quad .02$

Seniority

$.31 * * \quad .32 * * \quad .11$

$.21 * \quad .29 * \quad .21$

Political

Party

$.35^{* *}$

$--\quad--$

$.28 * *$

Race

.06

.14

.02

$.08 \quad--$

Gender

$.10 \quad .04$

$.07 \quad .10 \quad .03$

Educational

Level

.14

$.21 * \quad .11$

$.23 * \quad .26 * \quad .32 *$

Age

$.24 *$

$.24 * * .19$

$.10 \quad .10 \quad .38 *$

Occupational

Prestige

$.18 \quad .25^{*} \quad .19$

$.35 * * \quad .45 * * \quad .16$

Urban/Rural $\quad .08$

$.01 \quad .17$

.13

$.09 \quad .29 *$

District

Safety

$.20 * \quad .14 \quad .19$

.14

$.15 \quad .22$ 
Mark C. Ellickson and Donald E. Whistler

Table 4 (continued)

\begin{tabular}{ccccc}
\multicolumn{2}{c}{$1985-1986$} & & \multicolumn{2}{c}{$1987-1988$} \\
\cline { 4 - 5 } & Aggregate Demo & Rep & Aggregate Demo & Rep
\end{tabular}

Institutional

$\begin{array}{lllllll}\text { Position } & .28^{* *} & .28^{*} & .04 & .30^{* *} & .31^{* *} & .02 \\ \text { Seniority } & .24 * & .27^{*} & .18 & .22^{*} & .25^{*} & .19 \\ \begin{array}{l}\text { Political } \\ \text { Party }\end{array} & .37 * * & -- & -- & .38^{* *} & -- & -- \\ \text { Race } & .07 & .16 & -- & .08 & .17 & -- \\ \text { Gender } & .06 & .07 & .04 & .00 & .06 & .12\end{array}$

Educational

Level

$\begin{array}{lll}.17 * & .28 * & \end{array}$

.06

$.11 \quad .05$

Age

$.24 *$

$.25 * \quad .05$

.14

$.15 \quad .08$

Occupational

Prestige

.13

.23

.17

.08

$.07 \quad .04$

Urban/Rural

.12

.15

.02

.14

$.21 * \quad .01$

District

Safety

.10

$.25 * \quad .07$

.03

.13

.17

Reputation-

Effectiveness

$.49 * *$

$.44 * * \quad--$

Reputation-

Advice-Giver

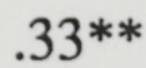

$.39 * * \quad .10$

${ }^{2}$ The coefficients in this table are eta coefficients. Eta is a measure of association where the dependent variable is interval level and the independent variable is nominal level.

'The groups with significantly larger means on the dependent variable, i.e., legislative effectiveness are, respectively: the leaders, senior members, Democrats, advanced degrees, younger members, high occupation prestige, urban districts, safe districts, and those members with reputations for effectiveness or advice-giving.

$* \mathrm{P}<.05$

$* * \mathrm{P}<.001$ 
Measuring Legislative Effectiveness in the Missouri General Assembly

\section{Table 5}

The Influence of Legislative, Personal, and District-Related Attributes on Reputations for Effectiveness and Advice-Giving in the Missouri House, 1987-88
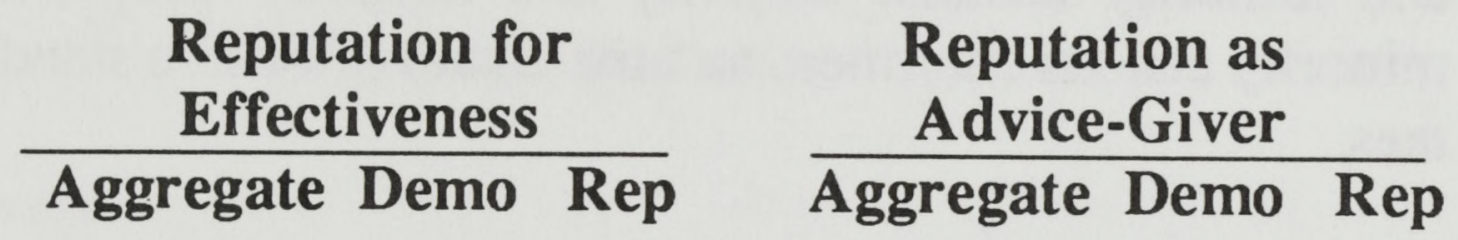

Institutional

$\begin{array}{lllllll}\text { Position } & .44 * * & .49 * * & .12 & .30 * * & .44 * * & .03 \\ \text { Seniority } & .12 & .15 & .07 & .12 & .12 & .12 \\ \begin{array}{l}\text { Political } \\ \text { Party }\end{array} & .25 * * & -- & -- & .02 & -- & -- \\ \text { Race } & .09 & .15 & -- & .10 & .15 & - \\ \text { Gender } & .05 & .09 & .05 & .08 & .07 & .11 \\ \text { Educational } & & & & & & \\ \text { Level } & .05 & .08 & .12 & .11 & .06 & .17 \\ \text { Age } & .07 & .07 & .13 & .09 & .12 & .13\end{array}$

Occupational

$\begin{array}{lllllll}\text { Prestige } & .09 & .06 & .17 & .06 & .06 & .17\end{array}$

Urban/Rural

$.06 \quad .06 \quad .20$

$.00 \quad .03 \quad .05$

District

Safety

.04

$.09 \quad .17$

.06

$.03 \quad .13$

${ }^{\mathrm{a}}$ The coefficients in this table are eta coefficients.

$* * \mathrm{P}<.001$ 


\section{Appendix A}

1. Leadership positions in the Missouri House include the speaker, speaker pro tempore, majority and minority leaders, assistant majority and minority leaders, majority and minority whips, majority and minority caucus chairmen, and the chairs of twelve standing committees.

2. The demographics of age, race, sex, occupation, education, as well as, seniority, were culled from the bibliographic write-ups and photographs in the 1959-60,1961-62, 1967-68, 1975-76, 1985-86, and 1987-88 Official Manuals (Jefferson City: Van Hoffman Press, Inc.)

\section{a. Educational Level}

beyond college college degree some college high school diploma less than high school diploma

b. Occupational Prestige

1. For the 1959-60, 1961-62, and 1967-68 sessions we used Robert Hodge's 1963 ranking of occupations. (See Robert W. Hodge, "Occupational Prestige in the United States, 19251963." American Journal of Sociology 70 (Nov. 1964): 286302.)

2. For the $1975-76,1985-86$, and 1987-1988 sessions we assigned a prestige score from the 1980 census occupational ranking to each legislator's occupation. (See Gillian Stevens and Elizabeth Hoisington, "Occupational Prestige and the 1980 U. S. Labor Force.” Social Science Research 16 (March 1987): 74-105.) 
c. Age

Young: $\quad$ 24-39 years old

Middle-aged: $\quad 40-55$ years old

Old: $\quad$ beyond 56 years old

d. Seniority

Junior Members - one term or less

Senior Members - two terms or more

3. Urban/rural was calculated in the following manner: Legislative districts whose boundaries encompassed less than one county (e.g., all districts in the St. Louis and Kansas City areas) were identified as urban, while legislative districts encompassing one or more counties were identified as rural.

4. Legislative district competitiveness was determined by the following formula:

$$
\frac{X}{X+Y}
$$

where $\mathrm{X}=$ winning candidate's vote total and $\mathrm{Y}=$ losing candidate's vote total.

Unsafe districts were designated as those in which the winning candidate garnered $55 \%$ or less of the total votes cast. Safe districts were those in which the winning candidate collected over $55 \%$ of the total votes cast. 


\section{References}

Bass, B. M. 1981. Stogdill's Handbook of Leadership. New York: The Free Press.

Best, J. J. 1971. "Influence in the Washington House of Representatives." Midwest Journal of Political Science, 15: 547-562.

Burns, J. M. 1978. Leadership. New York: Harper and Row.

Clapp, C. L. 1963. The Congressman. Washington, D.C.: The Brookings Institution.

Dahl, R. A. 1957. "The Concept of Power." Behavior Science 2 (July, 1957).

Dahl, R. A. 1976. Modern Political Analysis. Englewood Cliffs, N.J.: Prentice-Hall.

Dresang, D. L., \& Gosling, J. J. 1989. Politics, Policy, and Management in the American States. New York: Longman.

Fenno, R. F., Jr. 1966. The Power of the Pursue: Appropriations Politics in Congress. Boston: Little, Brown and Company.

Fenno, R. F., Jr. 1973. "The Internal Distribution of Influence: The House." In David Truman, ed., The Congress and America's Future. (63-90). Englewood Cliffs, N.J.: Prentice-Hall.

Francis, W. L. 1962. "Influence and Interaction in a State Legislative Body." American Political Science Review. 56: 953-961.

Francis, W. L. 1967. Legislative Issues in the Fifty States: A Comparative Analysis. Chicago: Rand McNally.

Frantzich, S. 1979. "Who Makes Our Laws? The Legislative Effectiveness of Members of the U. S. Congress.'Legislative Studies Quarterly, 4: 409-428.

Hamm, K. E., Harmel, R., \& Thompson, R. 1983. "Ethnic and Partisan Minorities in Two Southern State Legislatures.” Legislative Studies Quarterly, 8: 177-189.

Janda, K. F. 1972. "Towards the Explication of the Concept of Leadership in Terms of the Concept of Power." In Glenn Paige, ed., Political Leadership: Readings For An Emerging Field (45-68). New York: The Free Press.

Jewell, M. E. 1969. The State Legislature, Politics and Practice. New York: Random House.

Jewell, M. E., \& Patterson, S. C. 1966. The Legislative Process in the United States. (4th ed.) New York: Random House.

Keefe, W. J., \& Ogul, M. S. 1985. The American Legislative Process: Congress and the States. Englewood Cliffs, N. J.: Prentice-Hall.

Leuthold, D. A., \& Carter, J. 1981. “Missouri” In Leroy Hardy, Alan Heslop, and Stuart Anderson, eds., Reapportionment Politics (181-185). Beverly Hills: Sage.

Matthews, D. R. 1960. U.S. Senators and Their World. Chapel Hill: University of North Carolina Press.

Meyer, K. 1980. "Legislative Influence: Toward Theory Development Through Causal Analysis." Legislative Studies Quarterly, 5: 563-585.

Nechemias, C. 1987. "Changes in the Election of Women To U.S. State Legislative Seats.” Legislative Studies Quarterly, 7: 125-142.

Olson, D. M., \& Nonidez, C. T. 1972. "Measures of Legislative Performance in the U. S. House of Representatives." Midwest Journal of Political Science, 16: 269277.

Patterson, S. C. 1983. "Legislators and Legislatures in the American States." In Virginia Gray, Herbert Jacob, and Kenneth Vines, eds., Politics in the American States (135-179). Boston: Little, Brown and Company. 
Reynolds v. Sims, 84 S. Ct. 1362 (1964).

Rosenthal, A. 1974. Legislative Performance in the States. New York: The Free Press. Rosenthal, A. 1981. Legislative Life. New York: Harper and Row.

Rosenthal, A. 1989. "The Legislative Institution: Transformed annd at Risk." In Carl Van Horn, ed., The State of the States (69-101). Washington, D. C.: CQ Press.

Saffell, D. C. 1987. State and Local Government. New York: Random House.

Squire, P. 1988. "Member Career Opportunities and the Internal Organization of Legislatures." Journal of Politics, 50: 726-744.

Tickamyer, A. R. 1983. "Rural-Urban Influences on Legislative Power and Decision Making." Rural Sociology, 48: 133-147.

Whistler, D. E., \& Dunn, C. D. 1983. "Institutional Representation as Institutional Accountability in the Arkansas General Assembly." Arkansas Political Science Journal, 4: 40-55.

Whistler, D. E., \& Ellickson, M. C. 1988. "Measuring Influence in a Sothern State Legislature." Southeastern Political Review, 16: 155-178.

Wilson, W. 1956. Congressional Government. New York: World Publishing. 